JPPKMI 2 (1) (2021) 76-83
JURNAL PENELITIAN DAN PENGEMBANGAN
KESEHATAN MASYARAKAT INDONESIA
Jttps://journal.unnes.ac.id/sju/index.php/jppkmi

\title{
Riwayat Pemberian MP-ASI dan Sosial Ekonomi dengan Kejadian Stunting pada Balita
}

\author{
Astriya Hidayah $^{1}$, Yuliaji Siswanto ${ }^{1} \bowtie$, Kartika Dian Pertiwi $^{1}$ \\ ${ }^{1}$ Program Studi Kesehatan Masyarakat, Fakultas Kesehatan, Universitas Ngudi Waluyo
}

\section{Info Artikel}

Sejarah Artikel:

Diterima 3 Mei 2021

Disetujui 9 Juni 2021

Dipublikasi 13 Juni 2021

Keywords:

MP-ASI, status ekonomi,

stunting

URL:

https://journal.unnes.ac.j d/sju/index.php/ippkmi /article/view/47526

\begin{abstract}
Abstrak
Stunting merupakan kondisi gagal tumbuh pada anak balita akibat kurangnya asupan gizi yang bersifat kronik. Menurut WHO, Indonesia masuk ke dalam negara ketiga dengan kejadian tertinggi Asia Tenggara sebesar 27,7\%. Penelitian ini bertujuan untuk mengetahui hubungan riwayat pemberian MP-ASI dan status ekonomi dengan kejadian stunting pada balita di Desa Ngajaran Kecamatan Tuntang Kabupaten Semarang. Desain penelitian yang digunakan adalah analitik observasional dengan pendekatan kasus kontrol. Sampel penelitian sebanyak 88 balita terdiri dari 22 kasus dan 66 kontrol yang diambil dengan teknik simple random sampling. Data dianalisis menggunakan uji chi-square. Hasil penelitian menunjukkan ada hubungan antara riwayat pemberian MP-ASI dengan kejadian stunting pada balita dengan nilai $\mathrm{p}=0,004 ; \mathrm{OR}=4,929$ (CI 95\% 1,745-13,936); ada hubungan antara status ekonomi dengan kejadian stunting pada balita dengan nilai $\mathrm{p}=0,047 ; \mathrm{OR}=0,327$ (CI 95\% 0,120-0.890). Simpulan dalam penelitian ini adalah ada hubungan antara riwayat pemberian MP-ASI dan status ekonomi dengan kejadian stunting pada balita di Desa Ngajaran Kecamatan Tuntang Kabupaten Semarang.
\end{abstract}

\begin{abstract}
Stunting is a condition of failure to thrive in children under five due to a chronic lack of nutritional intake. According to WHO, Indonesia is the third country with the highest incidence in Southeast Asia at 27.7\%. This study aims to determine the relationship between the history of complementary feeding and economic status with the incidence of stunting in children under five in Ngjajaran Village, Tuntang District, Semarang Regency. The research design used was observational analytic with a case-control approach. The research sample was 88 toddlers consisting of 22 cases and 66 controls taken by simple random sampling technique. Data were analyzed using chi-square test. The results showed that there was a relationship between the history of complementary feeding and the incidence of stunting in toddlers with $p$ value $=0.004 ; \mathrm{OR}=4.929(95 \% \mathrm{CI}$ 1.745-13.936); there is a relationship between economic status and the incidence of stunting in children under five with $p$ value $=0.047 ;$ OR $=0.327$ (95\% CI 0.120-0.890). Closing: The conclusion in this study is that there is a relationship between the history of giving complementary feeding and economic status with the incidence of stunting in children under five in Ngajaran Village, Tuntang District, Semarang Regency.
\end{abstract}

(C) 2021 Universitas Negeri Semarang

Alamat korespondensi:

J1. Diponegoro no 186 Gedanganak - Ungaran Timur,

Kab. Semarang Jawa Tengah

E-mail: vuliaiisiswanto@unw.ac.id 


\section{PENDAHULUAN}

Stunting merupakan target dari Sustainnable Development Goal (SDGs) yang masuk pada tujuan pembangunan berkelanjutan yakni mengakhiri kelaparan, mencapai ketahanan pangan dan peningkatan gizi pada tahun 2030. Stunting atau rendahnya tinggi badan menurut umur merupakan indikator terjadinya gangguan pertumbuhan anak berupa kekurangan gizi kronis. Berdasarkan data global, sebesar 21,5\% anak umur dibawah 5 tahun mengalamistunting (WHO, 2019). Menurut United Nations Children's Emergency Fund (UNICEF) pada tahun 2017 lebih dari setengah balita stunting atau sebesar $55 \%$ di Asia dan lebih dari sepertiganya atau sebesar $39 \%$ di Afrika.. Berdasarkan data prevalensi balita stunting yang dikumpulkan oleh World Health Organizational (WHO), Indonesia termasuk ke dalam negara ketiga dengan prevalensi tertinggi di regional Asia Tenggara setelah Timor Leste, dan India.

Hasil riset kesehatan dasar mencatat prevalensi stunting di Indonesia pada tahun 2013 yaitu sebesar 37,2\% mengalami penurunan pada tahun 2018 sebesar 30,8\% dan berdasarkan SSGBI menjadi $27,7 \%$ pada tahun 2019. Sedangkan prevalensi stunting menurut provinsi pada balita yaitu tertinggi di provinsi Nusa Tenggara Timur sebesar 43,82\%, provinsi Jawa Tengah sebesar $27,68 \%$ dan prevalensi stunting terendah di provinsi Bali sebesar 14,42\% (SSGBI, 2019). Menurut Kemenkes RI, target penurunan stunting di Indonesia sebesar 14\% pada tahun 2024. Karenanya presentase balita pendek di Indonesia tergolong tinggi maka masih menjadi masalah kesehatan masyarakat yang perlu di tanggulangi

Menurut hasil laporan riset kesehatan dasar 2018 Provinsi Jawa Tengah, prevalensi balita stunting berdasarkan Kabupaten pada balita usia 0 - 59 bulan berada di Kabupaten Puworejo sebanyak 3,93\% dengan kategori sangat pendek dan kategori pendek sebanyak 19,40\% sedangkan di Kabupaten Magelang sebanyak $8,9 \%$ dengan kategori sangat pendek dan kategori pendek sebanyak $25,05 \%$ dan di Kabupaten Semarang sebanyak $8,16 \%$ dengan kategori sangat pendek dan kategori pendek sebanyak $16,71 \%$. Dimana prevalensi stunting berdasarkan usia balita $0-59$ bulan di Kabupaten Semarang prevalensinya lebih tinggi dibandingkan Kabupaten Purworejo.

Kementerian Kesehatan tahun 2018 Stunting merupakan suatu keadaan dimana anak balita mempunyai panjang atau tinggi badan yang kurang jika dibandingkan dengan umur. Keadaan ini diukur menggunakan satuan panjang atau tinggi badan yang lebih dari -2 SD median atau standar pertumbuhan anak dari WHO (Kemenkes, 2018). Dampak buruk yang ditimbulkan dari masalah gizi (Stunting) yaitu Jangka pendek menyebabkan perkembangan otak anak terganggu, kecerdasan anak menurun dan terganggunya perkembangan fisik serta metabolisme dalam tubuh mengalami gangguan Sedangkan dampak jangka panjang yakni menurunkan kemampuan kognitif dan prestasi belajar anak, daya tahan tubuh anak menurun sehingga anak mudah sakit, dan resiko munculnya penyakit degenerative

Stunting menjadi masalah karena dapat ditimbulkan dari stunting yaitu menurunnya potensi pertumbuhan fisik pada anak, penurunan perkembangan saraf dan fungsi kognitif serta peningkatan risiko penyakit kronis di masa dewasa (Onis MD dan Francesco B, 2016). Menurut Bappenas (2013) Faktor langsung yang mempengaruhi stunting yaitu asupan gizi balita dan penyakit infeksi seperti halnya cacingan, ISPA, diare. Sedangkan faktor tidak langsung mempengaruhi stunting yaitu ketersediaan pangan, pola asuh dan sanitasi air bersih atau pelayanan kesehatan.

Studi pendahuluan dilakuan pad $10 \mathrm{ibu}$ balita dan mendapatkan hasil sebanyak 3 balita mengalami stunting dan sebanyak 6 balita tidak mengalami stunting diketahui faktor yang dapat mempengaruhi stunting didapatkan hasil bahwa sebanyak 6 dari 10 ibu balita mempunyai pengetahuan tentang gizi yang kurang, 5 dari 10 ibu balita memberikan makanan pendamping asi secara dini, 4 dari 10 balita dengan keluarga berpendapatan rendah. Penelitian ini bertujuan 
untuk mengetahui hubungan antara pengetahuan giziibu, riwayat pemberian MPASI dan status ekonomi pada balita di Desa Ngajaran Kecamatan Tuntang Kabupaten Semarang.

\section{METODE}

Desain penelitian yang digunakan adalah analitik observasional dengan pendekatan kasus kontrol. Penelitian dilakukan pada bulan Januari 2021. Populasi penelitian adalah balita yang berusia 24-59 bulan pada tahun 2020 di Desa Ngajaran Kecamatan Tuntang Kabupaten Semarang. Sampel yang diambil sebanyak 88 balita yang terdiri dari 22 kasus dan 66 kontrol yang diambil dengan teknik simple random sampling. Kriteria yang digunakan untuk pengambilan sampel adalah jumlah anggota keluarga tidak lebih dari 4 , bersedia menjadi responden dan masih tinggal di Desa Ngajaran. Variabel yang diukur dalam penelitian ini adalah riwayat pemberian MP-ASI, status ekonomi dan kejadian stunting. Data dikumpulkan menggunakan kuesioner dan dianalisis secara univariat menggunakan tabel distribusi frekuensi, serta analisis bivariat menggunakan uji chi-square.

\section{HASIL DAN PEMBAHASAN}

Pada tabel 1 menunjukkan bahwa pada kelompok kasus lebih banyak responden memberikan MP-ASI pertama kali kepada anak yang tidak sesuai yaitu diberikan pada usia kurang dari 6 bulan dan lebih dari 6 bulan sebanyak 15 responden $(68,2 \%)$ sedangkan pada kelompok kontrol lebih banyak responden memberikan MP-ASI pertama kepada anak yang sesuai yaitu tepat pada usia 6 bulan sebanyak 46 responden (69,7\%). Pemberian MP-ASI diberikan kepada anak pada usia yang berbeda - beda antara lain saat usia 2 hari setelah melahirkan, usia 3 bulan, 5 bulan, 8 bulan, 12 bulan. Sebagian besar alasan ibu memberikan makanan pendamping ASI (MPASI) pada usia kurang dari 6 bulan dikarenakan anak yang sering menangis terus karena dianggap anak tersebut lapar dan pemberian MP-ASI lebih dari 6 bulan karena anak menolak atau tidak mau diberikan MP-ASI. Pada kelompok kontrol lebih banyak ibu yang memberikan MP-ASI secara sesuai yaitu pada usia 6 sebanyak 46 responden $(69,7 \%)$. Pada saat bayi berusia 6 bulan sistem enzim pencernaan sudah relative sempurna untuk mencerna makanan, mendapat imunitas yang cukup selama menyusui, dan mulainya stimulasi motorik bayi (Nugroho, 2011). Perilaku kesehatan dalam pemberian MP-ASI dapat dipengaruhi oleh faktor pengetahuan, pekerjaan, dan dukungan keluarga (Afriyani, 2016). Berdasarkan hasil penelitian di Desa Ngajaran didapatkan bahwa sebagian besar responden mempunyai ibu yang bekerja sebanyak 53 responden (60,2\%). Ibu yang mempunyai kesibukan bekerja, kurang dapat memberikan perhatian penuh kepada anaknya. Beban kerja dan kesibukannya yang ditaanggung mampu mengurangi perhatian ibu untuk dapat memberian makanan sesuai dengan usianya (Ismail, 2013).

Pada tabel 1 menunjukkan bahwa kelompok kasus lebih banyak pada tingkat status ekonomi tinggi yaitu sebanyak 14 responden $(63,6 \%)$ sedangkan pada kelompok kontrol lebih banyak pada tingkat status ekonomi rendah yaitu sebanyak 42 responden ( $63,6 \%$ ). Berdasarkan hasil penelitian kelompok kasus lebih banyak pada tingkat status ekonomi tinggi yaitu sebanyak 14 responden $(63,6 \%)$. Desa Ngajaran berdekatan dengan kawasan industry tekstil yang berada di Kecamatan Pringapus dan Kecamatan Bawen sehingga pendapatan tinggi rata - rata orang tua responden adalah sebagian karyawan pabrik, serta pegawai negeri/ PNS. Pendapatan keluarga dapat menentukan ketersediaan bahan pangan dalam keluarga baik dari segi kualitas dan kuantitas pangan yang dikonsumsi. Pada kelompok kontrol lebih banyak pada tingkat status ekonomi rendah yaitu sebanyak 42 responden ( 63,6\%). sebagian besar masyarakat menggantungkan hidupnya pada sektor usaha sehingga mayoritas pencaharian masyarakat di Desa Ngajaran adalah wiraswasta. oleh karena 
Tabel 1. Distribusi frekuensi riwayat pemberian MP-ASI dan status ekonomi pada balita di Desa Ngajaran Kecamatan Tuntang

\begin{tabular}{lllll}
\hline Variabel & \multicolumn{3}{c}{ Kejadian Stunting } \\
\cline { 2 - 5 } & Kasus & \multicolumn{3}{l}{ Kontrol } \\
\cline { 2 - 5 } & Frekuensi & $\begin{array}{l}\text { Persentase } \\
(\%)\end{array}$ & Frekuensi & Persentase (\%) \\
\hline $\begin{array}{l}\text { Riwayat Pemberian MP-ASI } \\
\begin{array}{l}\text { Tidak Sesuai (< } \\
\text { 6 bulan dan }>6\end{array}\end{array}$ & 15 & 68,2 & 20 & 30,3 \\
bulan) & & & & \\
$\begin{array}{l}\text { Sesuai (6 bulan) } \\
\text { Status Ekonomi }\end{array}$ & 7 & 31,8 & 46 & 69,7 \\
$\begin{array}{l}\text { Rendah } \\
\text { Tinggi }\end{array}$ & 8 & 36,4 & 42 & 63,6 \\
\hline
\end{tabular}

itu pendapatan yang diperoleh tidak menetap sehingga untuk memenuhi kebutuhan keluarga juga terbilang kurang. Menurut Khomsan (2012) status ekonomi sangat dipengaruhi oleh pendapatan keluarga, apabila akese pangan di tingkat rumah tanggal bermasalah karena kemiskinan maka masalah kurang gizi akan muncul.

Pada tabel 2 menunjukkan bahwa terdapat hubungan antara riwayat pemberian MP-ASI dengan kejadian stunting di Desa Ngajaran $(\mathrm{p}=0,004, \mathrm{OR}=4,929 ;$ CI 95\% 1,743 - 13,936). Riwayat pemberian MP-ASI yang tidak sesuai dengan usia balita berisiko 4,929 kali lebih besar untuk mengalami stunting dibandingkan dengan riwayat pemberian MPASI yang sesuai pada usia minimal 6 bulan. Mayoritas balita di desa ngajaran mempunyai ibu yang bekerja yaitu sebesar 53 responden (60,2\%). Menurut Hasrini (2017) ibu yang bekerja di luar rumah lebih besar memberikan makanan pendamping asi (MP-ASI) pada usia sebelum 6 bulan. Ibu yang sibuk bekerja biasanya menitipkan anaknya pada tetangga atau keluarga lainnya ketika jam kerja berlangsung sehingga pemberian makanan sering di lakukan oleh orang lain bukan dengan ibunya (Zahiruddin, Kogade, Kawalkar, Khatib dan Gaidhane, 2016). Dengan demikian sibuknya ibu bekerja cenderung memberikan makanan pendamping secara dini bahka terlambat.

Pemberian MP-ASI yang tidak tepat akan menimbulkan gangguan pada pencernaan dan status gizi anak. Pemberian MP-ASI pada balita secara dini dapat mampu meningkatkan resiko kejadian penyakit infeksi seperti diare karena MP-ASI yang diberikan belum tentu hygiene dan mudah di cerna oleh anak. Diare dapat di hubungkan dengan gagal tumbuh karena mengalami malabsorbsi zat nutrisi selama diarhea (Grantina, Elingarami, Manuel, 2020). pemberian MP-ASI secara dini menunda pemberian MP-ASI juga dapat menyebabkan kebutuhan nutrisi bayi tidak terpenuhi sehingga pertumbuhan dan perkembangan balita dapat terhambat karena kebutuhan gizi balita kurang terpenuhi. Pemberian MP-ASI yang tepat pada anak dapat menurunkan malnutrisi, karena pada usia 6 kebutuhan gizi anak yang kurang tidak dapat tercukupi hanya dengan ASI saja (Hariani, Sudarsono dan Yeni, 2018).

Pada tabel 2 menunjukkan bahwa terdapat hubungan antara status ekonomi dengan kejadian stunting pada balita di Desa Ngajaran Kecamatan Tuntang Kabupaten Semarang $(\mathrm{p}=0,047 \mathrm{OR}=0,327$; CI 95\% 0,120 - 0,890). Balita pada keluarga dengan staus ekonomi rendah memiliki risiko mengalami stunting 0,327 kali lebih kecil mengalami stunting dibandingkan status ekonomi keluarga yang tinggi. Mayoritas pekerjaan di Desa Ngajaran adalah wiraswasta dan karyawan pabrik sehingga pendapatan yang diperolehnya terkadang sesuai UMK dan ada yang tidak sesuai dengan UMK. Sebanyak 8 (36,4\%) responden dengan status ekonomi rendah memiliki balita mengalami stunting, sedangkan 
Tabel 2. Hubungan pengetahuan gizi ibu, riwayat pemberian MP-ASI dan ststus ekonomi pada balita di Desa Ngajaran Kecamatan Tuntang

\begin{tabular}{|c|c|c|c|c|c|c|c|}
\hline \multirow[b]{3}{*}{ Variabel } & \multicolumn{4}{|c|}{ Kejadian Stunting } & \multirow{2}{*}{$\begin{array}{l}\mathrm{p} \text { - } \\
\text { Value }\end{array}$} & \multirow[t]{2}{*}{ OR } & \multirow[t]{2}{*}{ CI 95\% } \\
\hline & \multicolumn{2}{|c|}{ Stunting } & \multicolumn{2}{|c|}{ Tidak Stunting } & & & \\
\hline & $\overline{\mathrm{f}}$ & $\%$ & $\mathrm{f}$ & $\%$ & & & \\
\hline Riwayat Pemberian MF & & & & & 0,004 & 4.929 & $1.743-13.936$ \\
\hline $\begin{array}{l}\text { ASI } \\
\text { Tidak Sesuai }(<6 \text { bula }\end{array}$ & & & & & & & \\
\hline dan $>6$ bulan) & 15 & 68,2 & 20 & 30,3 & & & \\
\hline Sesuai ( 6 bulan) & 7 & 31,8 & 46 & 69,7 & & & \\
\hline Status Ekonomi & & & & & 0,047 & 0,327 & $0,120-0,890$ \\
\hline Rendah & 8 & 36,4 & 42 & 63,6 & & & \\
\hline Tinggi & 14 & 63,6 & 24 & 36,4 & & & \\
\hline
\end{tabular}

pada kelompok ekonomi tinggi lebih banyak yaitu sebesar $14(63,6 \%)$. Sebagian ibu menyediaan makanan yang beranekaragam dengan nilai gizi yang baik sehingga kecil kemungkinan terjadi stunting pada balita.

Pendapatan keluarga berhubungan dengan pertumbuhan anak yang dapat diartikan bahwa pendapatan keluarga yang besar maka balita akan mendapatkan gizi yang baik (Sundari, 2020). Soekirman (2009) menyebutkan bahwa ekonomi yang baik dan pendidikan tinggi akan mampu dalam menyediakan makanan yang baik sehingga anak dapat tumbuh dan berkembang dengan baik. Namun dalam penelitian ini diketahui bahwa jumlah balitas stunting pada keluarga dengan tingkat ekonomi tinggi lebih banyak dibandingkan balita dengan keluarga dengan tingkat ekonomi rendah. Pendapatan keluarga yang tinggi dapat menyebabkan stunting pada balita walaupun keluarga mampu menyediakan makanan yang beranekaragam. Menurut anindita (2012) tingkat pendapatan yang tinggi belum tentu menjamin status gizi baik pada balita, karena tingkat pendapatan belum tentu teralokasi cukup untuk keperluan makan.

Pada tabel 1 menunjukkan bahwa kelompok kasus lebih banyak pada tingkat status ekonomi tinggi yaitu sebanyak 14 responden $(63,6 \%)$ sedangkan pada kelompok kontrol lebih banyak pada tingkat status ekonomi rendah yaitu sebanyak 42 responden ( $63,6 \%$ ). Berdasarkan hasil penelitian kelompok kasus lebih banyak pada tingkat status ekonomi tinggi yaitu sebanyak 14 responden (63,6\%).
Desa Ngajaran berdekatan dengan kawasan industry tekstil yang berada di Kecamatan Pringapus dan Kecamatan Bawen sehingga pendapatan tinggi rata - rata orang tua responden adalah sebagian karyawan pabrik, serta pegawai negeri/ PNS. Pendapatan keluarga dapat menentukan ketersediaan bahan pangan dalam keluarga baik dari segi kualitas dan kuantitas pangan yang dikonsumsi. Pada kelompok kontrol lebih banyak pada tingkat status ekonomi rendah yaitu sebanyak 42 responden $(63,6 \%)$. sebagian besar masyarakat menggantungkan hidupnya pada sektor usaha sehingga mayoritas pencaharian masyarakat di Desa Ngajaran adalah wiraswasta. oleh karena itu pendapatan yang diperoleh tidak menetap sehingga untuk memenuhi kebutuhan keluarga juga terbilang kurang. Menurut Khomsan (2012) status ekonomi sangat dipengaruhi oleh pendapatan keluarga, apabila akese pangan di tingkat rumah tanggal bermasalah karena kemiskinan maka masalah kurang gizi akan muncul.

\section{PENUTUP}

Simpulan dalam penelitian ini adalah ada hubungan antara riwayat pemberian MP-ASI dan status ekonomi dengan kejadian stunting pada balita di Desa Ngajaran Kecamatan Tuntang Kabupaten Semarang.

\section{DAFTAR PUSTAKA}

Aridiyah, F., Ninna R., Mury R. 2015. Faktor - 
faktor yang mempengaruhi kejadian stunting pada anak balita di wilayah pedesaan dan perkotaan (The Factors Affecting Stunting on Toddlers in Rural and Urban Areas). EJurnal Pustaka Kesehatan Vol 3 No 1: 163 170

Ambar, SW., Alfan, A.,dan Sri, W. 2020. Peningkatan Pengetahuan Ibu Hamil Dan Menyusui Melalui Pengembangan Model Dan Media Animasi Pemberian ASI Eksklusif Pada Bayi. Jurnal Iimiah Permas Stikes Kendal Vol 10. No. 1103 - 108

Anindita P. 2012. Hubungan Tingkat Pendidikan Ibu, Pendapatan Keluarga, Kecukupan Protein \& Zinc Dengan Stunting (Pendek) Pada Balita Usia 6-35 Bulan Di Kecamatan Tembalang Kota Semarang. Jurnal Kesehatan Masyarakat Vol 1 No 2 Hal 617 - 626 Universitas Diponegoro.

Asvia Fira. 2019. Determinan Kejadian Stunting Pada Balita Usia 24 - 59 Bulan Di Wilayah Kerja Puskesmas Grong - Grong Kabupaten Pidie Tahun 2019. Skripsi: Universitas Muhammadiyah Aceh

Ayu, Ni Komang Widyari. 2019. Hubungan Antara Pengetahuan Ibu Tentang Nutrisi Dengan Kejadian Stunting Pada Balita Di Desa Singakerta Kecamatan Ubud Kabupaten Gianyar Tahun 2019. Skrispi: Poltekkes Kemenkes Denpasar

Bappenas. 2013. Kerangka Kebijakan Gerakan Nasional Percepatan Perbaikan Gizi Dalam Rangka Seribu Hari Pertama Kehidupan (Gerakan 1000 HPK). Jakarta: Badan Perencanaan Pembangunan Nasional

Garcia, L,M., Gloria,G., Desiderio, R,S., Alfredo, S., Juan, F., Lluis, S. 2017. Factors Associated with Stunting among Children Aged 0 to 59 Months from the Central Region of Mozambique. Journal Nutrients 9(5) 491 https://doi.org/10.3390/nu9050491

Grantina, M., Elingarami, S., Emmanuel, M. 2020. Correlates of diarrhea and stunting among under-ive children in Ruvuma, Tanzania; a hospital-based cross-sectional study. Journal Elsevier 8(1) 2468 - 2276

Hariani., Sudarsono, R., Yeni, S. 2018. Analisis Data Hasil Pemantauan Status Gizi Dari Faktor Determinan Kejadian Stunting Pada Balita. Journal Health Information Vol 10 No 1 DOI: 10.36990/hijp.v10i1.123
Izwardy Doddy. 2020. Studi Status Gizi Balita Terintegrasi SUSENAS 2019. Jakarta : Balitbang Kementerian Kesehatan RI

Kementerian Kesehatan RI.2018. Situasi Balita Pendek (Stunting) Di Indonesia. Jakarta: Pusdatin Kementerian Kesehatan RI

Khomsan, A. 2012. Ekologi Masalah Gizi, Pangan, Dan Kemiskinan. Bandung: Alfabeta

Lutfia Tazkia. 2017. Hubungan Tingkat Sosial Ekonomi Dengan Kejadian Stunting Pada Balita Usia 24 - 59 Bulan Di Desa Karangrejek Wonosari Gunung Kidul. Skripsi:Universitas Aisyiyah Yogyakarta

Notoatmodjo, S. 2012,. Promosi Kesehatan dan Ilmu Perilaku. Jakarta. Rineka Cipta

Nugroho, T. 2011. Buku Ajar Obstetri untuk Mahasiswa Kebidanan edisi ke-2. Yogyakarta : Nuha Medika

Onis MD, Francesco B.2016. Childhood Stunting: A Global Perspective.World Health Organization. Licensed By Johnwiley \& Sons Ltd. Maternal \&

RISKESDA. 2019. LaporanProvinsi Jawa Tengah Riskesda 2018. Jakarta: Balitbangkes.

Saaka, M. 2014. Relationship between Mothers' Nutritional Knowledge in Childcare Practices and the Growth of Children Living in Impoverished Rural Communities. Journal Of Health Population And Nutrition 32(2): 237-248. Diakses dari https://www.ncbi.nlm.nih.gov/pmc/articles/ PMC4216960/

Soekirman. 2009. Ilmu gizi dan Aplikasinya. Direktorat Jenderal Pendidikan Tinggi Departeman Pendidikan Nasional. Jakarta

Virginia, A. Sugeng, M., Riva M. 2019. Hubungan Pemberian MP-ASI Dan Usia Pemberian MPASI Dengan Kejadian Stunting Pada Anak Usia 6 - 24 Bulan Di Desa Leyangan Kecamatan Ungaran Timur Kabupaten Semarang. Jurnal Gizi Dan Kesehatan Universitas Ngudi Waluyo Vol 12No. 27

Wawan A dan Dewi M. 2011. Teori dan Pengukuran Pengetahuan, Sikap, dan Perilaku Manusia. Cetakan II. Yogyakarta: Nuha Medika.

Wicaksono Aditya. 2018. Hubungan Pengetahuan Ibu Tentang Gizi Dengan Status Gizi Balita Studi Observasi Analitik Di Wilayah Kerja Puskesmas Bangetayu Kecamatan Genuk Kota Semarang Periode Februari - Maret 2018. Skripsi: Universitas Sultan Agung. 
Astriya, H., et al. / Riwayat Pemberian MP-ASI / JPPKMI 2 (1) (2021)

Widayatun. 2009. Ilmu Perilaku. Jakarta : Info Medika

Yulia Nur K \& Sundari. 2020. Hubungan Pendidikan dan Pendapatan Orang Tua dengan Pertumbuhan Balita. Jurnal Kebidanan Harapan Ibu Pekalongan. Vol 8 No 1
Zahiruddin, Q., Gaidhane, A., Kogade, P., Kawalkar, U., Khatib, N., \& Gaidhane, S. (2016). Challenges and Patterns of Complementary Feeding for Women in Employment: A Qualitative Study from Rural India. Current Research in Nutrition and Food Science Journal, 4(1), 48-53. 